\title{
THE NEW NORMAL? NATURAL RESOURCE DEVELOPMENT, Civil DisobedienCe, AND INJUNCTIVE RELIEF
}

\author{
Rick WiLliams, DiONYSIOS Rossi, \\ ClAy JACOBSON, AND TIM PRITCHARD*
}

\begin{abstract}
In recent years, contentious energy and pipeline projects have been mired in Aboriginal and environmental opposition, often leading to protests that involve civil disobedience. The authors argue that civil injunctions are increasingly considered to be the most appropriate method to resolve these events. Despite the inherent tension in using a civil lawsuit to enforce a public law, the judicial debate over whether to proceed through criminal or civil avenues has trended towards private law remedies. Consequently, entities who may be subject to interruptions caused by protests should be prepared to take measures to secure a civil injunction. The authors detail the legal steps required to receive injunctive relief and address some common pitfalls in enforcing these orders. Aboriginal rights and title concerns are also addressed.
\end{abstract}

\section{TABLE OF CONTENTS}

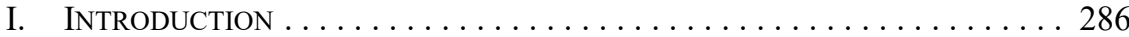

II. Protest AND CIVIL DisobediENCE $\ldots \ldots \ldots \ldots \ldots \ldots \ldots \ldots \ldots \ldots \ldots$

III. LAW ENFORCEMENT INVOLVEMENT

PRIOR TO INJUNCTION APPLICATION $\ldots \ldots \ldots \ldots \ldots \ldots \ldots \ldots . \ldots \ldots$

A. Civil Disobedience Policy and Judicial CRiticism . . . . . . . 288

B. HistoricAl UNDERSTANDING OF

LAW ENFORCEMENT POLICY . . . . . . . . . . . . . . . . . . . . 291

C. ReCEnT TRENDS . . ................................ 293

IV. OBtAINING INJUNCTIVE RELIEF . . . . . . . . . . . . . . . . . . . . 294

A. The Test . .................................. 294

B. Serious Question to Be Tried . . . . . . . . . . . . . . . . . 295

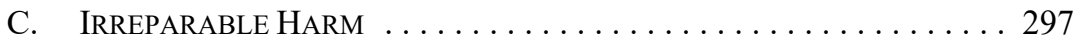

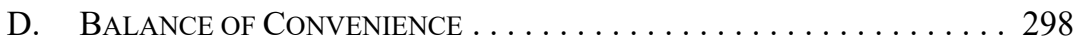

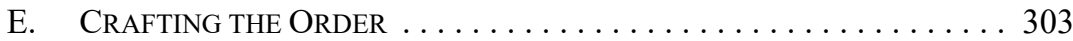

V. ENFORCING THE ORDER . . . . . . . . . . . . . . . . . . . . 304

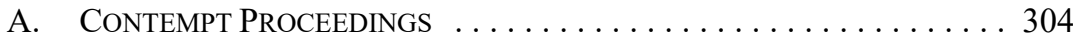

B. ENFORCEMENT ORDERS . . . . . . . . . . . . . . . 306

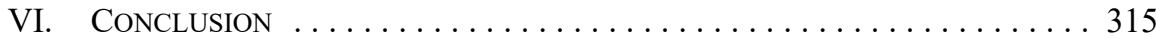

Rick Williams, Dionysios Rossi, and Tim Pritchard practice commercial litigation with an emphasis on energy, transportation, and environmental law at the Vancouver office of Borden Ladner Gervais LLP. Clay Jacobson practices commercial litigation with an emphasis on energy law at the Calgary office of Borden Ladner Gervais LLP. The authors would like to thank Jake Zhong, articled student, for his assistance in the preparation of this article. 


\section{INTRODUCTION}

Civil disobedience in the face of natural resource development has a long history on the west coast. ${ }^{1}$ In recent years, the focus of such activities has been major energy projects. Acts of civil disobedience, which by definition involve individuals wilfully disobeying public laws for the purpose of expressing political or social views, may give rise to an expectation that the criminal justice system will respond to enforce the law and ensure future compliance with it. Any such expectation would largely go unmet. Absent violence or threats to public safety, the criminal justice system will generally not intervene to prohibit civil disobedience. It is therefore left to private parties (usually project proponents) to bear the time and expense of seeking compliance with the law by bringing a civil lawsuit against protestors, obtaining an injunction, and then requesting that the court require (or encourage) police intervention.

Historically, courts have occasionally lamented being compelled to adjudicate matters that are inherently criminal in nature. Others have accepted the reluctance of police to unilaterally intervene. Despite this divergence, a review of recent jurisprudence suggests that the debate over whether civil injunctions are an appropriate means of resolving civil disobedience appears to have largely concluded in the affirmative. An injunction has emerged as the only practical remedy available to project proponents who may be impacted by civil disobedience. For this reason, the procedural requirements for obtaining (and then enforcing) civil injunctions have become increasingly significant.

In this article, we begin by examining recent instances in which injunctive relief was sought by a private party to address acts of civil disobedience. We then consider the various means of enforcing injunctions, in particular the requirement to obtain an "enforcement order," as well as the possibility of bringing contempt proceedings for continued noncompliance. Finally, we examine some lingering concerns about the current conceptual approach to resolving civil disobedience disputes through the use of civil injunctions, notwithstanding that it has emerged as the predominant form of relief in this context.

\section{Protest and Civil Disobedience}

At the outset, it is important to differentiate between civil disobedience and lawful protests. Although civil disobedience is used as a form of protest, from a legal perspective it is characterized as the wilful disobedience of public laws. The distinction has been described as follows:

Public protest per se may be completely legal. For example, groups assemble and march in public areas of a city to attract media attention to their issues. This sort of demonstration may incur no legal response. Distinct from this type of protest is the category of activity commonly described as civil disobedience. Civil disobedience involves members of the public intentionally breaking the law in the belief that they are following the dictates of a higher justice. ${ }^{2}$ This article will focus predominantly on developments in the law within Western Canada, particularly
given that British Columbia has been the jurisdiction with the most examples of civil disobedience leading to injunction proceedings.

2
Julia E Lawn, "The John Doe Injunction in Mass Protest Cases" (1998) 56:1 UT Fac L Rev 101 at 103. 
In Slocan Forest Products Ltd. v. Doe ${ }^{3}$ the Supreme Court of British Columbia emphasized this unique feature of civil disobedience:

"Civil disobedience" is defined in Black's Law Dictionary (7th edition) as:

"A deliberate but non-violent act of lawbreaking to call attention to a particular law or set of laws of questionable legitimacy or morality."

The Attorney General's appreciation of civil disobedience is not markedly different:

Civil disobedience presents a unique challenge for the justice system, as it involves the actions of normally law-abiding citizens seeking to change public policy by illegal means or interfere with the lawful interests of other citizens. Widespread reporting of acts of civil disobedience makes these actions increasingly attractive for a small minority who choose not to respect the normal democratic process. It is the role of the Attorney General to ensure the rule of law is preserved and the will of the majority prevails against the illegal acts of a few. ${ }^{4}$

Two important implications arise from the fact that civil disobedience involves the wilful violation of public law.

First, it means that an attempt to quell acts of civil disobedience is not necessarily an attempt to create a "protest free zone" where individuals are not free to exercise their constitutionally guaranteed right to freedom of expression. Instead, injunction applicants would likely characterize their application as a means of providing redress for illegal acts. The failure to appreciate this distinction has caused some reporters to describe injunction proceedings in respect of civil disobedience as "SLAPPs" (Strategic Lawsuits Against Public Participation — namely, lawsuits brought for the sole purpose of silencing critics). ${ }^{5}$ This, however, is incorrect, as the purpose of the application is not to silence critics but instead to prevent those critics from engaging in unlawful action that prevents lawful activity from taking place.

Second, given that civil disobedience necessarily involves the violation of public law, it is unclear as to whether a civil lawsuit amongst private parties is the appropriate mechanism for enforcing public laws. Thus, in Slocan, after reviewing the above-noted definitions of civil disobedience, the Court made the following comment:

This is to say that by definition acts of civil disobedience are not in essence civil disputes between individuals. Nevertheless the policy is that those who are, in effect, victimized by such activity should approach the court on the pretext that what is happening is a civil dispute between that bystander and the demonstrators. By this means, form takes its leave of substance $a b$ initio in these matters. ${ }^{6}$

2000 BCSC 150, [2000] BCTC 554 [Slocan].

Ibid at para 34 [emphasis omitted].

See e.g. Byron Sheldrick \& Samir Gandesha, "B.C. Pipeline-Protest Case Shows How Lawsuits Threaten Democratic Voices," Editorial, The Globe and Mail (26 November 2014), online: <https:// www.theglobeandmail.com/opinion/bc-pipeline-protest-case-shows-how-lawsuits-threaten-democraticvoices/article21789300>. 
The tension that arises from using a civil lawsuit as a means of enforcing the public law lies at the heart of the judicial debate over whether an injunction is the appropriate form of relief to address acts of civil disobedience.

\section{LAW ENFORCEMENT INVOLVEMENT Prior to InJUNCTION APPLiCATION}

\section{A. Civil Disobedience Policy and Judicial Criticism}

Acts of civil disobedience in the face of resource development typically constitute violations of various provisions of the Criminal Code ${ }^{7}$ in particular the prohibitions on blocking or obstructing a highway (section 423(1)(g)) and mischief (section 430). While there have been occasions on which law enforcement has intervened and made arrests (such as the 2009 Greenpeace protests at the Shell and Suncor oil sands sites ${ }^{8}$ ), this has not been standard practice. In many instances, law enforcement agencies and Crown counsel have adopted policies of not arresting or charging individuals for engaging in acts of civil disobedience unless there have been acts of violence or significant property damage. ${ }^{9}$ As a result, law enforcement and Crown counsel have routinely taken the position that they will not take action against individuals engaging in civil disobedience on their own initiative "leaving it instead to the affected private parties to seek civil relief through the courts."

On occasion, courts have criticized this position. ${ }^{11}$ One of the earliest and most widely noted such critiques came in Justice Wood's dissenting reasons in MacMillan Bloedel Ltd. v. Simpson. ${ }^{12}$ That case related to the Clayoquot Sound logging protests — an ongoing protest involving acts of civil disobedience occurring for several months in the early 1990s in response to MacMillan Bloedel's proposed logging activities. MacMillan Bloedel sought, and ultimately obtained, an injunction against the protestors (which included "John Doe" and "Jane Doe" as unnamed defendants).

On appeal, Justice Wood was of the view that a civil injunction granted against numerous unspecified defendants was not the appropriate means of proceeding, particularly given that an "alternative solution" was available — specifically, "the proper discharge of the

\section{RSC 1985, c C-46.}

See Lisa Arrowsmith, "Greenpeace Protestors Unfurl Banner at Alberta Shell Site," The Globe and Mail (3 October 2009), online: <https://www.theglobeandmail.com/news/national/greenpeace-protestersunfurl-banner-at-alberta-shell-site/article4195881 >; "21 Charged in Greenpeace Oilsands Protest," $C B C$ News (1 October 2009), online: <www.cbc.ca/news/canada/edmonton/21-charged-in-greenpeace-oil sands-protest-1.834154>.

9 In some cases, at least in British Columbia, this policy is explicit: see e.g. British Columbia, Ministry of Justice, Crown Counsel Policy Manual: Civil Disobedience and Contempt of Related Court Orders (Victoria: Criminal Justice Branch, 2014), online: $<$ https://www2.gov.bc.ca/assets/gov/law-crime-andjustice/criminal-justice/prosecution-service/crown-counsel-policy-manual/civ-1-civil-disobedience.pdf $>$ [Crown Manual]. A similar policy has been adopted by the RCMP: see the discussion in Amir Attaran, "Mandamus in the Enforcement of the Criminal Law: Ending the Anti-Protest Injunction Habit - Issues Arising from MacMillan Bloedel v. Simpson" (1999) 33:1 UBC L Rev 181.

10 MacMillan Bloedel Ltd v Simpson, [1996]2 SCR 1048 at para 8 [MacMillan Bloedel SCC], aff' g (1994), 118 DLR (4th) 1 (BCCA) [MacMillan Bloedel BCCA], aff'g (1993), 106 DLR (4th) 556 (BCSC) [MacMillan Bloedel BCSC].

11 Again, examples of such criticisms mostly arise in British Columbia. However, for an example from Ontario, see Canadian National Railway Co v Plain, 2012 ONSC 7356, 114 OR (3d) 27 [CNR].

MacMillan Bloedel BCCA, supra note 10. 
obligations which attach to the office of the Attorney-General." ${ }^{13}$ After quoting the provisions of the Criminal Code with respect to blockading a public highway and mischief, Justice Wood made the following comments:

\begin{abstract}
Any person who is the victim of a crime in this country is entitled to expect that appropriate steps will be taken to investigate the offence and to bring appropriate proceedings against the offender. By virtue of our constitutional structure, such functions are and always have been the responsibility of the executive branch of government, not the courts. It is the responsibility of the Attorney-General as the chief law enforcement officer ... to see to it that the criminal law is enforced. The role of the courts in such matters is to provide an independent and impartial process by which any resulting allegations can be fairly tried and a just result obtained.
\end{abstract}

It is only because the obligations of the office of Attorney-General have not been discharged, in connection with mass public protests which are designed to interfere with the exercise of private rights, that in recent years the courts have been drawn into a role which they were never intended to perform, and for which they are ill-suited. The inherent jurisdiction of the Supreme Court to punish for contempt of court is essential to the preservation of the due administration of justice. It is and always has been a jurisdiction to be exercised sparingly and as a last resort. It was never intended to be used to preserve law and order on our streets, or in our forests, any more than equity was ever intended to be used as an instrument of crowd control.

\begin{abstract}
And so it is that under our present constitutional structure, and within our existing legal framework, there exists the necessary authority to provide relief to an individual whose private rights are at risk as a result of a mass public protest for which the civil law in general, and equity in particular, has no effective solution. In those circumstances, I see no need for the Supreme Court to take the extraordinary step of assuming a jurisdiction which is incompatible with the fundamental premise underlying almost 900 years of its historical development, by making orders against non-parties. ${ }^{14}$
\end{abstract}

Ultimately, this view did not prevail. ${ }^{15}$ On further appeal to the Supreme Court of Canada, the injunction would be upheld, with Justice McLachlin (as she then was) stating that "[ $\mathrm{t}] \mathrm{he}$ mere fact that conduct may be characterized as criminal does not deprive a person whose private rights are affected from seeking relief in the civil courts." 16

Nevertheless, this critique of civil injunctions continued in subsequent cases by judges who similarly felt that the civil law was not the appropriate means of addressing the problem of civil disobedience. One such case was the Slocan decision noted above. Like MacMillan Bloedel, Slocan also involved an application for an order to enjoin acts of civil disobedience that were preventing lawful logging activities from taking place. Justice McEwan heard 
evidence from a RCMP representative who testified as follows with respect to the policies in place on civil disobedience:

S. Sgt. Buck: The policy that we have been using since I've been involved in Nelson is instructing if - if there is no violence or - or serious property damage, then we have been advising the party aggrieved to obtain a court injunction and arrange to have it served on the protesters. If it isn't obeyed, we ask them to go back to the court and get [an] enforcement order, after which time we take action. ${ }^{17}$

The Attorney General also provided extensive submissions on the roles of the Attorney General, Crown counsel and the RCMP, and the independence of each, and argued that there were several advantages to preferring the civil injunction process over criminal charges:

(1) There is a "cooling off" period in the period during [which] the private litigant gets its material together for an injunction application;

The process is not "criminalized";

(3) The practice avoids the police having to investigate the situation and allows the police to remain "neutral."18

Justice McEwan considered and rejected each of these rationales. With respect to the proposed "cooling off" period, Justice McEwan saw no reason why such tactics could not be utilized through effective policing:

I must say that I did not find the submissions in this regard very persuasive. The mechanisms available if the matters are prosecuted ranging from peace bonds, through diversion, on up to court proceedings offer every opportunity for a "measured" response. I was offered nothing that suggested that the police, acting responsibly under the [Criminal] Code, could not exercise the measure of restraint that the so-called "cooling off" period purportedly affords, or why violence is more likely if the police proceed in that manner than it is if the court articulates an injunction. ${ }^{19}$

As to the avoidance of "criminalizing" the process, Justice McEwan observed that resorting to the civil process frequently resulted in convictions for criminal contempt. ${ }^{20} \mathrm{He}$ also noted that the process is already criminalized given that by definition acts of civil disobedience involve committing criminal acts. ${ }^{21}$

Finally, with respect to the rationale of "efficiency" and remaining "neutral," Justice McEwan offered the following rejoinder:

The salutary effect of this state of affairs according to the authorities appears to be that it relieves them of the time and trouble to investigate the matter - offloading this burden onto affected bystanders - and that, at least

Slocan, supra note 3 at para 29.

Ibid at para 31.

Ibid at para 37.

Ibid at para 36.

Ibid at paras 36-37. 
anecdotally, the outcomes are much more satisfying: more "effective", "expeditious" and "more significant" in terms of penalties, to adopt the Attorney General's terms.

This is accomplished, of course, by recharacterizing behaviour that Parliament has already deemed to be socially harmful and punishable by law as conduct that defies the authority of the court.

In the context of an ordinary civil dispute police restraint and the maintenance of police neutrality may be very important. The police should not generally be seen to take sides in anything that is essentially a civil dispute (see Canada Post Corp. v. Canadian Union of Postal Workers (C.U.P.W.), 61 B.C.L.R. 2d 120, for a helpful discussion of such considerations). But in the face of genuine civil disobedience, which is quite another thing, it strikes me as a rather remarkable inversion of civics to preserve police neutrality at the expense of drawing the court itself into the fray in defence of its own authority. ${ }^{22}$

These comments animate the judicial critique of the policy of non-intervention in the face of civil disobedience: by forcing private parties to seek civil remedies rather than actually enforcing the Criminal Code, the burden of dealing with such problems is inevitably imposed on judges. Such concerns have been repeated in the years following the Supreme Court of Canada's seminal decision in MacMillan Bloedel. ${ }^{23}$

\section{B. HistoricAl UNDERSTANDING OF LAW ENFORCEMENT POLICY}

Implicit in these criticisms is a frustration at the possibility that segments of the public may view the courts as proponents of natural resource projects rather than impartial arbiters of the law. ${ }^{24}$ A corollary of this view is that law enforcement should bear the risk of being characterized in this manner, given its primary duty to enforce the law.

However, shifting the burden from the institution charged with law enforcement to one more removed from the situation on the ground may, in itself, be a compelling objective. The reason for this becomes more obvious when one considers the violent historical events that sometimes preceded the emergence of civil injunctions as the predominant form of relief.

One such example was the Oka Crisis of 1990. In the summer of 1990, a group of armed members of the Mohawk First Nation community of Kanesatake occupied a parcel of land

Ibid at paras 44-46 [emphasis in original].

See e.g. International Forest Products Limited v Kern, 2000 BCSC 1141, 45 CPC (4th) 92 [Kern BCSC] (but see the appeal on related contempt proceedings, Kern BCCA, supra note 15); International Forest Products Limited v Kern, 2000 BCSC 888, [2000] BCTC 373 [International Forest]; Alliford Bay Logging (Nanaimo) Ltd v Mychajlowycz, 2001 BCSC 636, [2001] BCTC 636; Regional District of Central Kootenay v Doe, 2003 BCSC 836, 228 DLR (4th) 252; British Columbia (Attorney General) $v$ Sager, 2004 BCSC 720, 29 BCLR (4th) 351 at paras 16-29.

24 See e.g. the comments of Justice McEwan in Slocan Forest Products Ltd $v$ John Doe, Jane Doe, and Persons Unknown, 2000 BCSC 1337, [2000] BCTC 895 at paras 15-16:

An unfortunate effect of this substitution of civil process for ordinary criminal enforcement is that the perception is created that the law is made by the judge who articulates it, and so I am asked to "take a stand for the environment" by one of the young men before me. That is rubbish, too. Let me make it clear that everything I have said throughout this and other cases like it, is that I view criminal behaviour as criminal behaviour. Period. The notion that idealism in the service of a cause is an excuse for lawbreaking is a disgrace. True idealism is informed by the mature realization that the only framework within which a society can truly be improved is a fundamental, not a selective, respect for the law. 
in southern Quebec near the village of Oka, which was slated to become a golf course, blockading a major transportation route in the process. After 78 days, the Mohawk members withdrew, but not before one police officer had been killed during an attempt to remove the Oka blockade by force. No charges were ever filed.

Protests supporting the Mohawks at Oka spread in Quebec and across the country, including a blockade of the British Columbia Rail line in August 1990 by members of the Seton Lake Indian Band. A day or two after a visit by Premier Vander Zalm, the RCMP removed the blockade. The event was extensively covered in the media and led to province wide protests in support of Aboriginal land claims. ${ }^{25}$

Another example occurred in September 1995, when a number of Aboriginal men, women, and youths entered and occupied Ipperwash Provincial Park in southwestern Ontario. They asserted that the Federal Government had promised to return the lands after a wartime appropriation of reserve land ran its course. Several altercations ensued between the Ontario Provincial Police (OPP) and the occupiers. During one altercation, Dudley George, a 38 year old Aboriginal man, was shot by an OPP officer and later died. The officer was eventually convicted of a criminal firearms offence. ${ }^{26}$

The event at Ipperwash sparked an enquiry by Commissioner (Justice) Sidney B. Linden, who delivered his Report of the Ipperwash Inquiry in 2007. ${ }^{27}$ The Ipperwash Report made many recommendations respecting land claims, Aboriginal relations, policing, and government-police interaction during protests involving acts of civil disobedience. The Ipperwash Report contains lengthy discussion as to how police must exercise caution and discretion when undertaking enforcement activities.

In British Columbia, there have been a number of significant Aboriginal protests and blockades, especially during the 1980s and 1990s. Chief among them was the Gustafsen Lake Standoff, which was a confrontation between the RCMP and Indigenous and nonIndigenous people during August and September 1995. The RCMP operation ended up being the most costly of its kind in Canadian history and involved 400 police officers with support from the Canadian Military. ${ }^{28}$ The predominantly Indigenous occupiers believed that privately owned ranch land was both sacred space and part of a larger tract of unceded Shuswap territory.

By the end of a 31-day standoff, there had been extensive shooting by police but, miraculously, no one was killed. Fourteen Indigenous and four non-Indigenous people were subsequently charged. A majority of those charged were found guilty and sentenced to jail

25 Nicholas Blomley, “'Shut The Province Down': First Nations Blockades in British Columbia, 1984-1995" (1996) 111 BC Studies 5 at 24.

"First Nation Tears Down Barriers Along Ipperwash Beach Near Park Where Ontario Police Killed Protester in 1995," National Post (7 December 2017), online: <nationalpost.com/news/canada/firstnation-tears-down-barriers-along-ipperwash-beach-near-park-where-ontario-police-killed-protester-in1995>.

27 The Honourable Sidney B Linden, Report of Ipperwash Inquiry (Toronto: Ipperwash Inquiry, 2007) [Ipperwash Report].

28 See generally Blomley, supra note 25. With regard to the Gustafsen Lake Standoff, see Scott Steele,"Legal Marathon: A B.C. Jury Convicts 15 in an Armed Standoff," Maclean's 110:22 (2 June 1997) 74, online: <www.macleans.ca>. 
terms ranging from six months to eight years. ${ }^{29}$ In the course of those proceedings, the argument that Canadian courts have no jurisdiction over offences committed on unceded Aboriginal lands was rejected on appeal. ${ }^{30}$

In contrast to these historical violent confrontations between protestors and law enforcement, more recent examples of civil disobedience involving civil injunctions have yielded different results. For example, in the Fall of 2014, numerous individuals engaged in civil disobedience in Burnaby, British Columbia to prevent Trans Mountain Pipeline ULC (Trans Mountain) from completing testing in support of its application for the approval of a proposed crude oil pipeline from Alberta to British Columbia. Police were on the scene monitoring the situation from the moment the protest began, but elected not to take action until after an injunction and enforcement order was obtained by Trans Mountain from the Supreme Court of British Columbia. One of the protestors described the enforcement of the injunction in these words:

\footnotetext{
Mostly the day was peaceful. With a few exceptions, the RCMP were friendly and polite, except when someone physically challenged them, and then their response was instant and overwhelming. One of them told me he was glad we were there standing up for what we believe. I suspect many agree with the protest, but they have a job to do. It's a tough spot for them to be in. ${ }^{31}$
}

Once Trans Mountain obtained the injunction, the police made numerous arrests in the above-noted manner (including an arrest of an 84 year-old grandmother ${ }^{32}$ ). However, despite the strongly-held and emotional views of the protestors, the injunction was enforced peacefully and without injury to police or protestors. ${ }^{33}$ This stands in stark contrast to the events noted above at Oka, Ipperwash, and Gustafsen Lake, where police initially intervened absent a court order.

\section{RECENT TRENDS}

Despite the fact that the civil injunction process has long been questioned as an appropriate means for responding to civil disobedience, recent decisions tend to adopt the civil injunction framework without criticism of police refusal to intervene. With very few notable exceptions, ${ }^{34}$ acceptance of the use of civil injunctions to provide redress to those impacted by civil disobedience has become standard. ${ }^{35}$ Furthermore, the means for enforcing

$29 \quad$ Ibid.

$30 \quad R v$ Ignace, 1996 CanLII 2474 (BCCA); $R$ v Ignace (1998), 156 DLR (4th) 713 (BCCA).

31 Bob Kull, "Kinder Morgan Protester: The RCMP Were Kind and Civil as They Arrested Me on Burnaby Mountain," Editorial, Vancouver Observer (24 November 2014), online: <https://www.vancouver observer.com/opinion/rcmp-were-kind-and-civil-they-arrested-me-burnaby-mountain-and-put-me-jail $>$.

32 "Pipeline Protest: Grandma Willing to go to Jail by Violating B.C. Court Order," CTV NewS (25 November 2014), online: <www.ctvnews.ca/canada/pipeline-protest-grandma-willing-to-go-to-jail-byviolating-b-c-court-order-1.2118868>.

33 Ian Bailey, "Protesters Rally Against Trans Mountain Pipeline, but Drilling Continues," The Globe and Mail (24 November 2014), online: <https://www.theglobeandmail.com/news/british-columbia/ protestors-rally-against-trans-mountain-pipeline-but-drilling-continues/article21743986/>.

34 One of which is another decision of Justice McEwan, who may be the last remaining critic of the policy against using criminal charges in response to civil disobedience: see Galena Contractors Ltd v Zarelli, 2014 BCSC 324, 2014 BCSC 324 (CanLII).

35 See e.g. DNT Contracting Ltd v Abraham, 2016 BCSC 1917, 2016 BCSC 1917 (CanLII) [DNT Contracting]; Peninsula Logging Ltd v Muirhead, 2016 BCSC 1921, 2016 BCSC 1921 (CanLII); Franzen v Doe, 2016 BCSC 1944, 2016 BCSC 1944 (CanLII); AJB Investments Ltd v Elphinstone Logging Focus, 2016 BCSC 734, 2016 BCSC 734 (CanLII) [AJB Investments]; British Columbia Hydro 
such orders are becoming increasingly streamlined and standardized (for example, by obtaining "enforcement orders" at the same time as the initial injunction, discussed in detail below).

Accordingly, parties faced with the prospect of project interruptions due to civil disobedience protests should expect to be required to take proactive steps to commence an action and secure an injunction as opposed to relying on the prospect of law enforcement intervening on their own accord.

\section{ObTAINing InJUNCTIVE RELIEF}

\section{A. The TeST}

The "tripartite test" set out by the Supreme Court of Canada in RJR-MacDonald Inc. v. Canada (Attorney General), ${ }^{36}$ requires an applicant for an injunction to prove the following:

1. A serious question to be tried (that is, a prima facie case on the merits);

2. irreparable harm will ensue if the injunction is not granted; and

3. the balance of convenience lies in favour of granting the injunction.

Courts have occasionally applied a two-part test set out in B.C. (A.G.) v. Wale, ${ }^{37}$ which combines the second and third element of the tripartite test, such that the applicant is only required to prove a fair question for trial and that the balance of convenience lies in favour of granting a stay. Generally speaking, when applying the two-part test, courts will still consider the question of irreparable harm in the context of the balance of convenience analysis. ${ }^{38}$ Thus, the distinction between the two versions of the test has been described as one "without practical effect." ${ }^{39}$ As other cases have emphasized, though, where the two-part test is applied, it is technically unnecessary to establish irreparable harm, meaning that the burden may be somewhat relaxed. ${ }^{40}$

Regardless of whether there is a practical difference between the two formulations of the test, recent trends in the jurisprudence appear to be confirming the three-part test set out in $R J R-$ MacDonald as the leading authority on this point. ${ }^{41}$

and Power Authority v Boon, 2016 BCSC 355, 1 CELR (4th) 141 [Boon]; Red Chris Development Company Ltd v Quock, 2014 BCSC 2399, 93 CELR (3d) 97 [Red Chris]; Trans Mountain Pipeline ULC $v$ Gold, 2014 BCSC 2133, 92 CELR (3d) 258 [Trans Mountain]; Produits Forestiers Arbec SENC $v$ Doe, 2013 NBQB 361, 414 NBR (2d) 357; SWN Resources Canada Inc v Claire, 2013 NBQB 328, 411 NBR (2d) 239; CNR, supra note 11; Nalcor Energy v NunatuKavut Community Council Inc, 2012 NLTD(G) 175, 330 Nfld \& PEIR 233, rev'd 2014 NLCA 46, 358 Nfld \& PEIR 123 [Nalcor NLCA]. [1994] 1 SCR 311 [RJR-MacDonald].

(1986), [1987] 2 WWR 331 (BCCA), aff'd [1991] 1 SCR 62.

See e.g. Yahey $v$ British Columbia, 2017 BCSC 899, 2017 BCSC 899 (CanLII) at para 34.

Coburn v Nagra, 2001 BCCA 607, 96 BCLR (3d) 327 at para 7. See also Expert Travel Financial Security (ETFS) Inc v BMS Harris \& Dixon Insurance Brokers Ltd, 2005 BCCA 5, 249 DLR (4th) 367 at para 54 .

$40 \quad$ Kern BCSC, supra note 23 at para 29.

41 See each of the cases referenced at supra note 35. 


\section{B. Serious Question to Be Tried}

Given that an injunction is premised upon civil wrongdoing, it is necessary to precisely plead specific causes of action against the defendants in the claim, even if the purpose of the claim is not to recover damages but rather to obtain an interlocutory or interim injunction. The first part of the test addresses whether there is an arguable case for such causes of action - in other words, whether the claim is frivolous or vexatious. ${ }^{42}$

Subject to exceptions described below, the burden of establishing a serious question to be tried is low. This aspect of the test is important, however, because it forces the party seeking an injunction to formulate specific causes of action against the persons engaging in civil disobedience, even though there may be no appetite to pursue those claims through to trial. Typically, such causes of action usually involve all or a combination of trespass, assault, nuisance, intimidation, conspiracy, unlawful interference with economic relations, and inducing breach of contract.

Although the burden is generally low, some evidence (usually by affidavit) must be adduced to demonstrate that there is a factual basis for an arguable case on behalf of the applicant. ${ }^{43}$ The injunction application brought by Trans Mountain in response to civil disobedience aimed at preventing it from carrying out mandatory testing activities provides a helpful illustration of the evidence that is usually advanced on such applications. Trans Mountain alleged that the protestors committed the tort of assault and that they caused contractors to feel unsafe. One of Trans Mountain's contractors swore an affidavit stating the following:

\footnotetext{
The protesters verbally attacked us, and stood in the way of our work. The protesters obstructed us from carrying on with the brush clearing. They screamed and yelled at us, and blasted megaphones in our ears. They moved very close to us while doing so, making it very comfortable [sic], especially for my hearing. They told us that we should not be there, and that they would prevent us from conducting our work. I felt intimidated by the protesters and did not feel safe. ${ }^{44}$
}

The evidence adduced by Trans Mountain was mocked in the press and on social media. In particular, the press took note of the emphasis, during the hearing of the application, on the threatening facial expressions of protestors (evidently tendered in support of the assault claim, which requires the apprehension of harm). This led to the creation of the sarcastic Twitter hashtag “\#KMFace,” where people opposed to Trans Mountain's activities posted an image of themselves online with an angry facial expression, along with the hashtag. Notably, one such image was posted by Gregor Robertson, the Mayor of Vancouver, an opponent of the project. $^{45}$

Red Chris, supra note 35 at para 48, citing RJR-MacDonald, supra note 36 para 55.

Boon, supra note 35 at para 54 .

Trans Mountain, supra note 35 at para 84.

James Keller, "Pipeline Politics Becoming a Factor in Vancouver and Burnaby Civic Elections," Vancouver Sun (12 November 2014), online: <www.vancouversun.com/Pipeline+politics+becoming+ factor+Vancouver+Burnaby+civic+elections/10374980/story.html $>$. 
The Court took a different view. Associate Chief Justice Cullen reached the following conclusion on the basis of the evidence put forward by Trans Mountain:

In my view, on the evidence advanced, a court could conclude that the torts of assault and intimidation are made out, given the misuse of the bullhorns, when coupled with the aggressive and threatening language, and the general and specific efforts to physically block the plaintiff's representatives from accessing their work sites. In other words, the plaintiff's representatives were faced with either physical confrontation or retreat. They wisely chose the latter. ${ }^{46}$

In addition to direct affidavit evidence from representatives of the company impacted by the civil disobedience (such as the affidavit sworn by the Trans Mountain representative noted above) in support of a prima facie cause of action, social media evidence is becoming an increasingly important source of such evidence in injunction proceedings. Mass protests involving acts of civil disobedience are often organized via social media. It is common for those engaged in such activities to post videos or photographs of their actions online in public forums. All of this can be employed as evidence in support of an injunction. For example, in CNR, the applicant provided evidence in the form of a YouTube video showing uniformed officers of the Sarnia Police participating in acts of civil disobedience along with other protestors. ${ }^{47}$ Similarly, in Boon, BC Hydro presented evidence from social media, including the defendants' postings on Facebook describing the airlifting of a building by helicopter onto the work site. ${ }^{48}$ Although such evidence is often hearsay, the court has the discretion to admit such evidence at the first stage of the analysis on an injunction application. $^{49}$

Some courts have held that where an application is brought to enjoin protestors from demonstrating, the court will impose a higher burden on the applicant to establish each of the constituent elements of the causes of action pleaded, given that the application may amount to a final determination of the action. ${ }^{50}$ For example, in Siksika Nation, the Alberta Court of Queen's Bench considered an injunction application brought on behalf of the Siksika Nation against certain of its members that had set up a blockade preventing a construction contractor from completing a subdivision to replace housing lost to flooding in 2013. The Court recognized that while the general rule is that a judge should not engage in an extensive review of the merits, there are rare exceptions where a more extensive review must be undertaken, including when the result of the interlocutory motion will in effect amount to a final determination of the action. The Court held that the exception was applicable in the context of the protest at issue, and applied the following test to determine whether the Applicant had established a strong prima facie case:

Trans Mountain, supra note 35 at para 113.

CNR, supra note 11 at para 25 .

Boon, supra note 35 at para 45.

Ibid at para 43, citing Le Soleil Restaurant Inc v Nomani, 2005 BCSC 1804, 2005 BCSC 1804 (CanLII) at para 47.

50 Siksika Nation v Crowchief, 2016 ABQB 596, 44 Alta LR (6th) 351 at paras 27-31 [Siksika Nation], citing Hudson Bay Mining \& Smelting Co, Limited v Dumas, 2014 MBCA 6, 370 DLR (4th) 237; International Forest, supra note 23 at para 41; Relentless Energy Corporation v Davis, 2004 BCSC 1492, 34 BCLR (4th) 336 at para 13 [Relentless Energy]. 
[T] he evidence must be such as to demonstrate that: (i) the plaintiff has a legal right of one nature or another and (ii) the defendant is interfering with that right in [an] actionable manner. Each of the constituent elements of the cause or causes of action upon which the court is being asked to act (including the elements of each of the associated torts) must be made out with sufficient certainty, in light of the governing standard, to warrant the sought-after relief. ${ }^{51}$

Given the potential emphasis that may be placed on the first prong of the tripartite test, and the higher standard that may be applied to establish a strong prima facie case in the context of a protest, it is incumbent on applicants for injunctions in the context of civil disobedience to ensure that evidence is adduced to establish each constituent element of the cause(s) of action alleged in the claim.

Furthermore, as we will discuss below, the strength of the plaintiff's case is a relevant consideration when determining the balance of convenience at the final stage of the analysis.

\section{IRREPARABLE HARM}

Irreparable harm was defined in $R J R-$ MacDonald as harm of such a nature that it cannot be compensated in damages. ${ }^{52}$ In ordinary injunction cases, this will often mean that proof of economic loss alone is not sufficient since such losses can be recovered in the form of a damages award once a judgment has been pronounced on the merits following a trial. In the case of civil disobedience, however, courts have been willing to accept proof of economic losses resulting from the delay of a project to establish irreparable harm, given that such losses are unlikely to be recovered through an award of damages. ${ }^{53}$ Accordingly, courts have routinely held that proof of interference with a business as an ongoing concern in these circumstances is sufficient to establish irreparable harm. ${ }^{54}$ As the Manitoba Court of Appeal recently stated, "[i]t is well settled that a finding of a complete blockade of a lawful business strongly suggests irreparable harm for the purposes of an injunction." ${ }^{, 5}$

There are other factors somewhat unique to civil disobedience cases that make it easier to establish irreparable harm than in injunction applications in other contexts.

In the context of civil disobedience, some courts have applied a reduced emphasis on the irreparable harm and balance of convenience stages of the analysis. For example, in Hamilton (City) v. Loucks, ${ }^{56}$ the Ontario Superior Court noted that where an injunction application involves an alleged breach of a municipal bylaw, and the applicant is able to

Siksika Nation, ibid at para 31, citing RWDSU, Local 558 v Pepsi-Cola Canada Beverages (West) Ltd (1998), 167 DLR (4th) 220 (Sask CA). RJR-MacDonald, supra note 36 at 341.

See e.g. Trans Mountain, supra note 35 at para 118.

AJB Investments, supra note 35 at para 31; West Fraser Mills v Members of Lax Kw'Alaams, 2004 BCSC 815, 2004 BCSC 815 (CanLII) at paras 21-22; Kern BCSC, supra note 23; MacMillan Bloedel BCSC, supra note 10; Tlowitsis-Mumtagila Band v MacMillan Bloedel Ltd (1990), [1991] 4 WWR 83 (BCCA) at 92; McLeod Lake Indian Band v British Columbia (1988), [1989] 4 CNLR 83 (BCSC). Hudson Bay Mining \& Smelting Co v Dumas, 2014 MBCA 6, 370 DLR (4th) 237 at para 86. (2003), 232 DLR (4th) 362 (Ont Sup Ct). 
establish a serious issue to be tried, an injunction will usually follow. The Court applied this same rationale to applications to enjoin civil disobedience, as follows:

\begin{abstract}
The same analysis has been made where an injunction is sought to prohibit ongoing civil disobedience by a defendant. There is no doubt that there is a strong public interest in ensuring that all of the citizens in our society obey the law. Therefore, there is a presumption that the courts will grant interlocutory injunctions to compel compliance with the law.... Any court tolerance of a continuing breach of the law will be extremely rare. $^{57}$
\end{abstract}

In addition, where the applicant is able to make out a prima facie case of trespass, courts will assume that irreparable harm will follow given that trespass is actionable per se, without proof of damages. ${ }^{58}$

Furthermore, in cases of civil disobedience for the purpose of delaying or preventing natural resource projects from proceeding, evidence showing that harm to contractors, employees or other third-parties will ensue is often sufficient to establish irreparable harm. The importance of such evidence was emphasized in Red Chris:

[I]rreparable harm may be caused when a blockade forces a company to downsize, as a result of unemployment which affects workers, their families, and their communities. The emotional and psychological effects of long-term unemployment are harms that cannot be compensated through damages. ${ }^{59}$

Even if an applicant believes it has enough evidence to satisfy this branch of the test, it is prudent to adduce as much evidence as possible to establish the harm that will ensue. This is because the magnitude of such harm will be a relevant consideration for the court on the balance of convenience inquiry.

\title{
D. Balance of Convenience
}

\section{GenERAL PRINCIPLES}

At the final stage of the analysis, courts must consider whether it is just or convenient to grant the injunction. A court may consider any relevant factors at this stage. However, "[ $\mathrm{t}] \mathrm{he}$ elements usually considered include: examination of the status quo; the strength of the plaintiff's case; the relative magnitude of the harm; and whether the public interest is engaged. $" 60$

With respect to the status quo, defendants in injunction applications in the circumstances relevant to this article often take the position that the status quo is represented by maintaining the land in its natural state. Essentially, their argument is that the project would disrupt the

$58 \quad$ Boon, supra note 35 at para 59; Board of School Trustees of School District No 27 (Cariboo-Chilcotin) $v$ Van Osch, 2004 BCSC 1827, 2004 BCSC 1827 (CanLII) at para 14. See also Calgary Airport Authority v Canadian Centre for Bio-Ethical Reform, 2014 ABQB 493, [2014] 11 WWR 397. Supra note 53 at para 68, citing Snuneymuxw First Nation v HMTQ, 2004 BCSC 205, 26 BCLR (4th) 360 [Snuneymuxw].

$60 \quad$ Boon, supra note 35 at para 69. 
status quo. This argument succeeded in Relentless Energy, ${ }^{61}$ which concerned a road that had received a valid permit. The Court refused to grant the injunction:

In the case at bar, the road has not yet been built. The defendants have been hunting and trapping in this area in the preceding years right up to the present. The status quo is preserved by denying the injunction.

In conclusion, I dismiss the plaintiff's application for an injunction because ... the balance of convenience favours preserving the status quo. ${ }^{62}$

This line of reasoning does not appear to have been followed in more recent cases, which have held that assuming that the status quo is maintained by delaying the project would amount to a collateral attack on the permits and authorizations giving rise to such activity, and would require the court to speculate as to the result of any pending judicial reviews or statutory appeals of the underlying authorization. ${ }^{63}$ As noted in Trans Mountain:

This Court is faced with the state of affairs as they exist today, not as they may become in the future. What the defendants are in effect asking this Court to do is to assess the merits of the appeals before the Federal Court of Appeal and the British Columbia Court of Appeal and decide whether a stay should be issued in one or another of those Courts if one were sought by Burnaby. I am in no position to make that assessment. ${ }^{64}$

With respect to the public interest, the fact that natural resource development injunctions are typically brought pursuant to some statutory authorization also affects this aspect of the balance of convenience. While defendants may wish to argue that the project at issue is not in the public interest, the fact that the government has issued the necessary authorization is strong evidence of where the public interest lies. Thus, the public interest aspect of the test involves "a high level of respect for the decisions of the legislative and executive branches of government." 65 For example, where the project has been through an environmental assessment process (which necessarily involves a consideration of the public interest), it has been held that " $[\mathrm{t}]$ he interests of the public in the integrity of the environmental assessment process" will usually outweigh the interests of the defendants. ${ }^{66}$

\section{ABORIGINAL AND TREATY RightS CASES}

Special considerations have been applied in the balance of convenience enquiry when the persons who will be enjoined are First Nations who oppose the project on the grounds of interference with their constitutionally protected Aboriginal or treaty rights. An example may be found in a 2008 decision from the Ontario Court of Appeal: Frontenac Ventures

Supra note 50 .

Ibid at paras $25-26$.

Boon, supra note 35 at paras 72-73; DNT Contracting, supra note 35 at paras 41, 47, citing Boon, ibid. Supra note 35 at para 76 . This case illustrates the increasing occurrence of civil disobedience during the course of regulatory proceedings that will determine whether a company has the right to engage in a certain industrial activity, rather than waiting until the company actually attempts to commence that activity. For example, the National Energy Board was recently forced to cancel two days of hearings into the proposed Energy East pipeline in response to violent and disruptive protests inside the hearing room: Benjamin Shingler \& Stephen Smith, "NEB Cancels 2 Days of Energy East Hearings in Montreal After "Violent Disruption," CBC News (29 August 2016), online: <www.cbc.ca/ 1.3739215>.

65 Snuneymuxw, supra note 59 at 71.

$66 \quad$ Tsay Keh Dene Band v British Columbia (Minister of Environment, Lands \& Parks) (1997), 24 CELR (NS) 66 at para 30 (BCSC). 
Corporation v. Ardoch Algonquin First Nation. ${ }^{67}$ That case concerned an appeal of sentences imposed on various members of the Ardoch Algonquin First Nation after they failed to comply with an injunction granted by the Ontario Superior Court in relation to a blockade of a proposed mine. After concluding that the sentences imposed were too harsh and allowing the appeal, the Court made the following non-binding statements:

Having regard to the clear line of Supreme Court jurisprudence, from Sparrow to Mikisew, where constitutionally protected aboriginal rights are asserted, injunctions sought by private parties to protect their interests should only be granted where every effort has been made by the court to encourage consultation, negotiation, accommodation and reconciliation among the competing rights and interests. Such is the case even if the affected aboriginal communities choose not to fully participate in the injunction proceedings.

Where a requested injunction is intended to create "a protest-free zone" for contentious private activity that affects asserted aboriginal or treaty rights, the court must be very careful to ensure that, in the context of the dispute before it, the Crown has fully and faithfully discharged its duty to consult with the affected First Nations. ${ }^{68}$

These comments have been quoted in subsequent injunction decisions. For example, in dismissing a proposed injunction application against members of a First Nation in Taseko Mines Ltd. v. Phillips, ${ }^{69}$ Justice Grauer of the Supreme Court of British Columbia quoted these comments and added the following:

This leads me to the public interest aspect of the balance of convenience. I fully accept Taseko's submission that it is in the public interest for Taseko to obtain the best available information for the purpose of informing the environmental assessment process. I do not, however, see that interest as being significantly at risk should the petitioners obtain their injunction, for the reasons just discussed.

On the other hand, it is also very much in the public interest to ensure that, in circumstances such as these, reconciliation of the competing interests is achieved through the only process available, being appropriate consultation and accommodation. Those duties, of course, attach to the Crown. Nevertheless, from the perspective of Taseko, that process is a cost and condition of doing business mandated by the historical and constitutional imperatives that are at once the glory and the burden of our nation. Only by upholding the process can reconciliation be promoted; without reconciliation, nothing is accomplished. This interest, in my view, is at risk should the injunction be denied, and weighs heavily in the balance of convenience.

The geology will always be there. The ore bed is not going anywhere. The same cannot be said of the habitat that is presently left to the petitioners. Once disturbed, it is lost. Once lost, the exercise of aboriginal rights is further diminished. ${ }^{70}$

2008 ONCA 534, 91 OR (3d) 1 [Frontenac Ventures].

Ibid at paras 46, 48.

2011 BCSC 1675, 64 CELR (3d) 84 [Taseko Mines].

Ibid at paras 59-60, 66 . 
These statements are difficult to reconcile with more recent authorities like Boon and DNT Contracting ${ }^{71}$ which suggest that an injunction application is not the appropriate proceeding in which to consider whether the government has engaged in sufficient consultation or consideration of Aboriginal interests. In this regard, more recent authorities cite in support the Supreme Court of Canada's decision in Behn v. Moulton Contracting Ltd., ${ }^{72}$ which was released after Frontenac Venutures and Taseko Mines.

Behn concerned a blockade of an access road to a logging site. The logging company brought a civil claim against the members of the blockade, who were members of the Fort Nelson First Nation (signatories to Treaty 8). The defendants claimed that their actions were lawful because the relevant forestry licenses had been granted without sufficient consultation, in violation of their treaty rights. The logging company applied to strike their defence. ${ }^{73}$

The Supreme Court of Canada held that it was an abuse of process to raise the sufficiency of consultation in the context of a private action, noting that it was open to the defendants to challenge such consultation through other venues (for example, a treaty action or judicial review of the underlying permits). Justice LeBel summarized the Supreme Court's reasoning as follows:

In my opinion, the Behns' acts amount to an abuse of process. The Behns clearly objected to the validity of the Authorizations on the grounds that the Authorizations infringed their treaty rights and that the Crown had breached its duty to consult. On the face of the record, whereas they now claim to have standing to raise these issues, the Behns did not seek to resolve the issue of standing, nor did they contest the validity of the Authorizations by legal means when they were issued. They did not raise their concerns with Moulton after the Authorizations were issued. Instead, without any warning, they set up a camp that blocked access to the logging sites assigned to Moulton. By doing so, the Behns put Moulton in the position of having either to go to court or to forgo harvesting timber pursuant to the Authorizations it had received after having incurred substantial costs to start its operations. To allow the Behns to raise their defence based on treaty rights and on a breach of the duty to consult at this point would be tantamount to condoning self-help remedies and would bring the administration of justice into disrepute. It would also amount to a repudiation of the duty of mutual good faith that animates the discharge of the Crown's constitutional duty to consult First Nations. The doctrine of abuse of process applies, and the appellants cannot raise a breach of their treaty rights and of the duty to consult as a defence. ${ }^{74}$

The issue of whether courts should consider the adequacy of consultation when determining the balance of convenience on an injunction was expressly considered in Nalcor. ${ }^{75}$ In that case, the appellants argued that special circumstances applied in the balance of convenience branch of the injunction test where Aboriginal rights are concerned, citing 
Frontenac Ventures and Taseko Mines in support. The Court of Appeal expressly rejected that submission:

The appellants assert, in effect, that there is a different test, or at least a super-added requirement, for the granting of an injunction where issues involving the duty to consult and accommodate aboriginal claims are involved. They say that Frontenac Ventures requires the court to address three questions as a pre-condition to granting injunctive relief: (i) whether every effort has been made by the court, to encourage consultation, negotiation and accommodation; (ii) whether the party with the duty to consult and accommodate has fully and faithfully discharged its duty to consult; and (iii) whether every effort has been exhausted to obtain a negotiated or legislated solution to the dispute before it.

In asserting this, the appellants are reaching too far. Their propositions are not supported by authority.... The two trial level decisions where the appellants assert the Frontenac approach was applied (Taseko Mines Ltd. v. Phillips, 2011 BCSC 1675 and Canadian Forest Products Ltd. v. Sam, 2011 BCSC 676 .. did not purport to apply the comments of MacPherson J.A. in Frontenac Ventures, quoted above, as a separate precondition for the granting of an injunction. Rather, those comments were simply discussed in the context of whether the second (irreparable harm) and third (balance of convenience) parts of the test for granting an interlocutory injunction were met. They certainly do not stand for the appellants' three propositions outlined above.

Furthermore, the import of the recent decision of the Supreme Court of Canada in Behn v. Moulton Contracting Ltd., 2013 SCC 26, [2013] 2 S.C.R. 227 works against the appellants' propositions. In that case, the Supreme Court held, among other things, that it was an abuse of process for individual aboriginal litigants to plead, as a defence to a tort action by a logging company based on a blockade of the company's logging site, that certain authorizations which the Crown had issued to the company were void due to an alleged failure by the Crown to consult. The individual aboriginal litigants had decided not to contest, by way of legal challenge, the validity of the authorizations when they were issued but, instead, employed self-help by subsequently erecting a blockade of the site. That situation has affinities with the present case. ${ }^{76}$

The foregoing suggests that there is no separate test or unique preconditions for the granting of an injunction against Aboriginal defendants who raise Aboriginal or treaty rights in their defence. Even where the defendants have undertaken what the Supreme Court in Behn suggested to be the appropriate course of action (namely, seeking judicial review), courts will not presume the success of such a challenge when considering whether to issue an injunction. As noted in Trans Mountain, until such judicial review is successful, the Court on an application for an injunction is only permitted to consider "the state of affairs as they exist today, not as they may become in the future." ${ }^{77}$

These comments were echoed in Boon, where the defendants to the injunction had commenced judicial review proceedings, which had not yet been adjudicated. In granting the injunction in that case, the Court made the following comments with respect to the balance of convenience where Aboriginal rights are raised as a defence:

$76 \quad$ Ibid at paras $35-37$.

77 Supra note 35 at para 76 . This analysis arguably would not apply where the activity in question takes place on reserve land, as the First Nation would have established property rights. There is little case law on this topic, at least in the context of civil disobedience. However, a recent decision granted an injunction in favour of a recycling company who sought to use an access road travelling through reserve land after the First Nation passed a bylaw specifically prohibiting such activity: see Revolution Infrastructure Inc v Lytton First Nation, 2016 BCSC 1562, 2016 BCSC 1562 (CanLII). 
As in Behn, if I were to give effect to their argument, it would be tantamount to condoning self-help remedies and would bring the administration of justice into disrepute.

The proper step for those who oppose the issuance of the authorizations is to challenge them by legal means. In this case, the two First Nations have done so and are awaiting the result of that judicial review. Those parties attempted to obtain an injunction to stop work on the Project pending determination of that judicial review, but the application was denied.... I asked counsel for the Named Defendants why his clients should be permitted to try to achieve indirectly, by way of protests, the result that the First Nations were not able to achieve by legal means. He submitted that there would be nothing inconsistent about two different injunction applications failing, as each must be decided on the evidence before the court. While that statement is obviously correct, it does not respond to the concern which is raised by this case. If I were to take into account the alleged breach of treaty rights or breach of the duty to consult, I would be endorsing an indirect attack on other proceedings which have been determined or are in the process of being determined. Applications seeking to halt work on the Project pending determination of the appeals or the judicial review proceeding should be brought to the courts hearing those issues. The arguments in support of putting a stop to the Project should not be raised indirectly in this courtroom. As noted by our Court of Appeal in Sam, at para. 24, it "is a recipe for delay and gridlock" if issues regarding Aboriginal rights and title which are to be determined in one forum are permitted to be argued or re-argued in a case which does not raise them directly.

Given the circumstances of this case, I adopt the comments of Pitfield J. in British Columbia Transmission Corporation v. Lemoignan, 2008 BCSC 1045 at para. 31. Our society works and functions on the basis of the rule of law.... As stated by Pitfield J. at para. 31, "[t]he rule of law requires that when the processes have been followed and completed, as they have in this case, those who have been granted the rights... must be permitted to proceed." 78

Accordingly, since the Behn decision was released in 2013, a number of courts have refused to determine the merits of arguments based on Aboriginal and treaty rights, and alleged failures in consultation, in the context of an injunction application.

\section{E. Crafting The ORder}

When seeking an injunction, it is important to provide the court with specific language to include in the order that is being sought. Consideration must be given to issues such the timing of the injunction (whether it will be a time-limited interim injunction or an interlocutory injunction that will remain in effect until judgment) and the geographic boundaries to which the injunction will apply.

With respect to timing, careful consideration should be given to whether the injunction should be time-limited. If the activities at issue can be accomplished within a relatively short window, it may not be necessary to grant an interlocutory injunction that would remain in place until after a trial on the merits - particularly given that in most cases there will be no which involved competing injunction applications: one by the mining company to remove the blockade, and one by the defendants to stay the relevant authorization pending judicial review on the basis of insufficient consultation. The Court ruled in favour of the defendants. 
appetite to take the matter forward to trial. If an interlocutory injunction is granted without time limitations, and the action is not prosecuted with sufficient diligence, the court may reconsider and dissolve the injunction. ${ }^{79}$

The geographic boundaries to which the injunction will apply is another important consideration for an applicant to consider. Where the activity contemplated is limited to a specific area, crafting an injunction with overly broad geographic limits (or none whatsoever) gives rise to the risk that an application will be dismissed on the grounds that it is overly broad. Such an order may reasonably be perceived as an attempt to completely quell lawful protest and freedom of expression. Moreover, an application for an injunction seeking relief that goes beyond what is required to achieve the stated objective can be dismissed for being overbroad. ${ }^{80}$

Where geographic limitations are included, however, it is crucial that they be described accurately. The failure to do so may result in an injunction being granted that is not subsequently enforceable in contempt proceedings. This very situation occurred in the Trans Mountain case. After the injunction was granted, it came to the attention of the applicant that the GPS coordinates contained in the order were not accurate. The Court granted an amendment to the order (which was not opposed) correcting these coordinates. ${ }^{81}$ The Court also noted, however, the potential impact on any contempt proceedings for those who were arrested for violating the order, stating that "prompt attention should be brought to the likely impact of the flawed description in the original order on any contempt applications in this case, with a view to an application to vacate the undertakings and the promises to appear relating to the bringing of any of the affected parties before the court." ${ }^{, 82}$

Finally, care should be used when drafting the injunction order to ensure that its terms are clear. Where the order is crafted using vague or ambiguous language that may lead to confusion, the application may be dismissed, ${ }^{83}$ or, as discussed below, may be unenforceable in contempt proceedings.

\section{ENFORCING THE ORDER}

\section{A. Contempt Proceedings}

The traditional remedy for intentionally violating an injunction is a contempt of court proceeding. There are two forms of contempt proceedings: civil (brought within the underlying civil proceeding) and criminal (brought by the Attorney General, who will be responsible for prosecuting the proceeding). Typically, criminal contempt requires proof of "public defiance" of the order. ${ }^{84}$ The elements of the offences are the same, although there are differences in sentencing options, as well as the stigma associated with the proceeding.

See e.g. TCT Canada Logistics Inc v Nordeen, 1999 BCCA 597, 181 DLR (4th) 74.

See e.g. Doubleview Capital Corp v Day, 2016 BCSC 231, 2016 BCSC 231 (CanLII) at para 79.

Trans Mountain Pipeline ULC v Gold, 2014 BCSC 2403, 2014 BCSC 2403 (CanLII).

Ibid at para 14.

JTT Electronics Ltd v Farmer, 2014 BCSC 2413, 62 CPC (7th) 237.

United Nurses of Alberta $v$ Alberta (Attorney General), [1992] 1 SCR 901 [United Nurses]. 
A party commits the offence of contempt by the "intentional doing of an act which is in fact prohibited by the order." ${ }^{15}$ The moving party must establish that:

1. The contemnor had personal service or knowledge of the order; and

2. the contemnor "deliberately or wilfully or knowingly did some act that was designed to result in the breach of a court order." 86

To establish a breach, the contemnor need not have intended to breach the order or put themselves in contempt. The moving party need only prove the contemnor wilfully did some act, which resulted in the breach of the order. ${ }^{87}$ Good faith belief that an order is constitutionally invalid or is likely to be set aside on appeal is not grounds to refuse to comply with a court order. The proper procedure to attack an order issued erroneously, even if it is an ex parte order, is to apply to the court to vary or vacate the order. As the Ontario High Court of Justice put it in Ontario (Ontario Securities Commission) v. Gaudet:

\footnotetext{
[O]ne could not ignore an order of this court simply because one held the opinion that it was ineffective on constitutional grounds, or on any other grounds. The order stood, and must be obeyed, until it was reversed on appeal, or an equally effective order was secured to the effect that it need not be obeyed. If that were not so, any order of the court which on its face was plainly directed to everyone could be disobeyed by those who held the opinion that they were not subject to it. Thus, the mere opinion, which may be wrong, elevates he who holds it to the level of the court, and wipes the order off the record. In my opinion, it is not only novel, it is fallacious. The proper way to establish, or seek to establish, that the prohibition was not effective was on an application to this court for leave. ${ }^{88}$
}

The purpose of a contempt finding is not simply to provide a remedy to the moving party, but to uphold the dignity of the court and protect the proper administration of justice. ${ }^{89}$

As a practical matter, however, a private party who seeks an injunction may not have the preservation of the rule of law as its overriding concern when considering whether to bear the time and expense to bring contempt proceedings. Retroactive punishment for breaching an injunction order does not achieve the objective of preventing the enjoined behaviour. Thus, except perhaps in cases of repeated and ongoing acts of civil disobedience, where punitive measures may be necessary to prevent defendants from repeating their actions (specific deterrence) and to deter others (general deterrence), contempt proceedings may be an unnecessary expense for a private party to bear. Accordingly, where the practical objective of allowing the necessary work to be completed can be achieved through other means, that may be preferable. In this regard, enforcement orders, which specifically authorize law enforcement officials to take measures to enforce an injunction, are increasingly becoming the predominant means of achieving that result. 


\section{B. ENFORCEMENT ORDERS}

\section{PROCEDURAL CONSIDERATIONS}

As noted earlier, law enforcement agencies have adopted a policy of non-intervention in respect of civil disobedience until a civil injunction has been granted. Even after an injunction is granted, however, further steps are often required before police will typically begin making arrests. Specifically, in non-violent situations, law enforcement officials will generally refrain from arresting individuals who violate the injunction without an additional "enforcement order" that specifically authorizes them to enforce the injunction.

Until recently, such enforcement orders were not usually granted at the same time as the injunction order itself. A two-step process was normally required: it was necessary to first obtain the injunction, serve it on the protesters, and then go back to court with a second application for an enforcement order with evidence that the injunction was not being obeyed. The second application required affidavit evidence concerning the service of the order and the protesters' refusal to comply with its terms.

From a conceptual standpoint, the rationale for this two-step process remains unclear. As a matter of law, police officers are already able to enforce a court order without a further order from the court expressly authorizing them to do so. Section 127 of the Criminal Code specifically prohibits the wilful violation of a court order. Given this, it is perhaps unsurprising that some Canadian courts have expressed confusion about this requirement and a reluctance to accept it. For example, in Finning Ltd. v. U.M.W., ${ }^{90}$ Justice Vickers granted an injunction that included an express enforcement order in a labour dispute context, but also expressed disapproval of the perceived need for enforcement orders:

\footnotetext{
I want to say for the record that orders of this court should be enforced without an enforcement order. The police authorities have a public duty, as well as a duty to this court, to enforce its orders without any further direction. It is only because the police authorities for some reason consider this to be outside of the duties they normally undertake and because of the potential for violence in this case and as well, because of the remoteness of the area that I am prepared to make the enforcement order. I repeat, I remain of the view that court orders should not have enforcement provisions because it is the duty of the police to enforce them without any further direction. ${ }^{91}$
}

Nevertheless, tepid support for the inclusion of an enforcement provision in an injunction order can be found in the Supreme Court of Canada's decision in MacMillan Bloedel:

The appellant ... has questioned the appropriateness of including a provision authorizing the police to arrest
and detain persons breaching the injunction. She argues that no authorization or direction from the court is
necessary to enable the police to act. The respondent accepts that the authorization is superfluous, and states
that it is included only because the police have requested such wording. No objection to this term was made
before Hall J. and it is not suggested that it vitiates the order. In these circumstances, this Court need not 
consider it further. I observe only that the inclusion of police authorization appears to follow the Canadian practice of ensuring that orders which may affect members of the public clearly spell out the consequences of non-compliance. Members of the public need not take the word of the police that the arrest and detention of violators is authorized because this is clearly set out in the order signed by the judge. Viewed thus, the inclusion does no harm and may make the order fairer. ${ }^{92}$

There is also some early authority supporting the use of an enforcement provision in an original order in exceptional circumstances. In Canada Post Corp. v. C.U.P.W., Justice Macdonald set out the following set of principles with respect to enforcement orders:

1. While s. 127 of the Criminal Code is available in this province as a means of enforcing an order of this court, it is not a practical alternative in disputes of this nature in light of the present policies of the R.C.M.P. and the Vancouver City Police.

2. Those policies, designed to ensure that the police are regarded as impartial in any civil dispute, are supported by sufficient logic to dictate against an outright clash between the court and the law enforcement agencies which direct the police.

3. Rule 56 procedures [for contempt] should be considered as the first alternative where there is apparent disobedience of an order of this court in a civil proceeding. Those procedures allow for the "measured response" in civil disputes which is emphasized by the law enforcement authorities.

4. Enforcement orders ... containing arrest and detention provisions should be included in the original injunction order only in unusual situations. The court will continue to expect its orders to be obeyed with or without such a provision. When those orders are not obeyed, proceedings for contempt of court are the appropriate remedy.

5. Prima facie proof of the breach of an order of this court should normally be a condition precedent to the granting of an enforcement order, as it is to the issuance of a R. 56(5) warrant.

6. Large numbers of potential contemnors, flagrant disregard of an injunction, events occurring in a remote geographical area, identification difficulties and other such problems may dictate ... in favour of an enforcement order in a given situation. ${ }^{93}$

The final principle set out in this case - setting out the circumstances in which an enforcement order may be included in the initial order - has been interpreted more broadly in recent years, leading to a departure from the original two-step procedure for obtaining such relief. Several recent cases illustrate this point. In Boon, the Court noted the following circumstances in which an enforcement order will be included in the injunction:

Enforcement orders are generally granted in circumstances where the location of the protest is remote; the number of participants varies from day to day and may be difficult to identify; the protesters have disregarded signs, or indicated they will disobey an injunction order; there are safety concerns; the time for the plaintiff 
to perform the work being blocked is limited; and, the RCMP have indicated they will not enforce the injunction order without enforcement terms. ${ }^{94}$

The Court concluded that all of these circumstances were present in that case. Similar conclusions were reached and enforcement orders were granted in AJB Investments and DNT Contracting. ${ }^{95}$ In Trans Mountain, an enforcement order was granted without any consideration as to the above noted factors, even though the activities took place in an urban setting.

Practically speaking, these recent cases appear to suggest that an enforcement order will be included in any case where law enforcement will not enforce an injunction without such an order. Given that the RCMP appears to have adopted a policy of requiring such orders in non-violent situations, injunction applicants should seek to include enforcement provisions in the original injunction order itself to avoid the need to return to court for a separate order before the injunction will be enforced.

\section{CRAFTING THE ENFORCEMENT ORDER}

Pursuant to the decision in British Columbia (Attorney General) v. Mount Currie Indian Band,${ }^{96}$ the following are standard terms to be considered for enforcement orders in British Columbia:

1. Any peace officer is authorized to arrest and remove any person who the peace officer has reasonable and probable grounds to believe is contravening or has contravened the provisions of this Order; ${ }^{97}$

2. any peace officer who arrests and removes any person pursuant to this Order is authorized to:

a) release that person from arrest upon that person undertaking in writing to appear before this Court at such time and place as may be fixed in the Notice for the purpose of being proceeded against for contempt of court or of fixing a date for such a proceeding and such other undertakings as the peace officer may deem appropriate; or

b) where such person has refused to give such written undertaking or where in the circumstances the peace officer considers it necessary, to bring forthwith such person before this Court at [nearest courthouse], British Columbia or such other place as the Court may direct for the purpose of being proceeded against for contempt of court or of fixing a time for such proceedings, and a peace officer

More recently the standard template includes another sentence in this paragraph: "For the sake of clarity, such a peace officer retains his or her discretion to decide whether to arrest or remove any person pursuant to this Order." 
may, where circumstances dictate, detain such person until it is possible to bring such person before the Court.

TAKE NOTICE that if you, the bodies or persons affected by this Order neglect to obey this Order, you will be liable to process of execution and proceedings for attachment and contempt.

In Telus Communications Inc. v. T.W.U., ${ }^{98}$ Justice Burnyeat further refined and strengthened an enforcement order he had previously issued due to continuing violations of an injunction order. After canvassing Attorney General and RCMP submissions on the issue of enforcement, Justice Burnyeat stated the following:

\begin{abstract}
Despite my considerable frustration with the positions taken by the Province and by peace officers including the R.C.M.P., it is clear that private litigants such as the Plaintiffs will have to continue to seek the assistance of the Court to enforce orders of this Court and that it will be necessary for orders granted to include an enforcement clause before peace officers will fulfill their public duty as well as their duty to this Court to enforce orders without further direction rather than attempting to act as neutral mediators when labour disputes or civil disobedience protests arise. Even though their statutory mandate is to enforce the law including orders of the Court, it remains necessary for the Court to tell peace officers that they should do what they are already required to do. ${ }^{99}$
\end{abstract}

In Telus, Justice Burnyeat discussed the use of Criminal Code section 127, which deals with disobeying a court order. He concluded that enforcement orders should contain a notice regarding section 127 and other potential offences under the Criminal Code. This wording has yet to receive higher judicial approval and may not be considered a standard requirement for inclusion in enforcement orders. ${ }^{100}$ Justice Burnyeat's notice provision read as follows:

TAKE NOTICE that if you, the bodies or persons affected by this Order neglect to obey this Order, you will be liable to process of execution and proceeding for attachment and contempt and that your activities may well allow a peace officer and any member of the Royal Canadian Mounted Police to come to the conclusion that they have reasonable and probable grounds to believe that you should be arrested under one or more of the following offences set out in the Criminal Code:
(a) Section 31:
(b) Section 127:
(c) Sections 265-269:
(d) Section 270:
(e) Section 423(1)(c):
(f) Section 423(1)(f):
(g) Section 423(1)(g):
(h) Section 430(1):

breach of the peace;

disobeying a Court order;

assault and causing bodily harm;

assaulting a peace officer;

persistent following;

watching and besetting;

blocking or obstructing a highway;

mischief to property, including; interference with lawful use, enjoyment or operation of property. ${ }^{101}$ 
In one recent Order granted by the Alberta Court of Queen's Bench on 24 January 2017 in Nova Gas Transmission Ltd. v. Montgrand, ${ }^{102}$ the Court expressly authorized members of the RCMP to arrest individuals that contravened the Order. However, the Order preserved the discretion of RCMP members as follows:

3. Any police officer with the Royal Canadian Mounted Police is hereby authorized to arrest and remove any person who the police officer has reasonable and probable grounds to believe is contravening or knowingly has contravened the provisions of this Order. For the sake of clarity, such a peace officer retains his or her discretion to decide whether to arrest or remove any person pursuant to this Order. ${ }^{103}$

\section{POLICE DisCRETION TO ENFORCE INJUNCTIONS}

As will be seen from the standard terms of enforcement orders noted above, such orders "authorize" the intervention of law enforcement. They do not specifically direct such intervention. In other words, while courts may expect the spirit of injunction and enforcement orders to be enforced (subject to police discretion to maintain public safety, as well as their own), an enforcement order is not a form of mandamus. It does not compel any government entity, including law enforcement, to do anything. This fact was noted in Red Chris Development v. Quock, where the Court stated that the enforcement order "preserves police discretion, although I suggest that an Order of this Court should be regarded as requiring the police to take action if there is resistance to obeying it."104

In some circumstances, law enforcement officials may treat the absence of a specific order requiring intervention as permission to refuse to intervene. An example of such nonintervention comes from the $C N R^{105}$ injunction case discussed earlier. In that case, a number of individuals had set up a blockade of a railway. The individuals participating in the blockade refused to identify themselves but said that the reason for the blockade had nothing to do with Canadian National $(\mathrm{CN})$ but instead was to apply pressure on the federal government with respect to the passage of Bill C- $45,{ }^{106}$ the federal omnibus budget bill that included amendments to the Navigable Waters Protection Act, ${ }^{107}$ the Fisheries Act, ${ }^{108}$ and the Canadian Environmental Assessment Act. ${ }^{109}$ Some of the individuals purported to be affiliated with the "Idle No More" movement, which presented itself as a grassroots movement seeking to prevent the erosion of treaty and Aboriginal rights.

Eventually, Ron Plain, one of the individuals and a member of the Chippewas of Sarnia First Nations, identified himself. When he was asked to leave, he refused, and indicated that he had no control over the other participants.

\footnotetext{
102 Fort McMurray 1713-00047 (Alta QB).

103 Ibid.

1042006 BCSC 1472, 2006 BCSC 1472 (CanLII) at para 39.

105 Supra note 11.

106 A second Act to implement certain provisions of the budget tables in Parliament on March 29, 2012 and other measures, 1st Sess, 41st Parl, 2012 (as passed by the House of Commons 5 December 2012) [Bill C-45].

RSC 1985, c N-22. Renamed the Navigation Protection Act by Bill C-45.

RSC 1985, c F-14.

SC 1992, c 37. Replaced by the Canadian Environmental Assessment Act, 2012, SC 2012, c 19, s 52. See generally CNR, supra note 11 at paras $1-17$.
} 
Shortly thereafter, CN obtained an ex parte interim injunction, effective from 21 to 27 December, directing the individuals to leave the area. On 27 December, counsel for CN appeared before Justice Brown and advised that the blockade continued, and moreover, that the Sarnia Police Chief had refused to enforce the initial injunction Order. In addition to a continuation of the injunction, $\mathrm{CN}$ asked Justice Brown to set dates for a motion in which a contempt order would be sought against Ron Plain and a motion requiring the Sarnia Police Chief to attend to explain the steps (if any) the police had taken to enforce the Order. As noted earlier, one of the pieces of evidence filed by $\mathrm{CN}$ was a YouTube video entitled "Sarnia Police Officers drumming at the Aamjiwnaang First Nation Blockade Dec. 26, 2012." " The video showed a uniformed, three-chevroned Sarnia Police officer participating with a number of the protestors in a drumming ceremony.

Justice Brown described numerous efforts made by $\mathrm{CN}$ to engage the Sarnia Police. ${ }^{11}$ However, at the continuation hearing, no representatives of the Sarnia Police appeared before Justice Brown and he noted:

[N]o representative of the Sarnia Police saw fit to appear in court today, notwithstanding service of CN's motion on Sarnia Police Deputy Chief Bob Farlow on December 24 at 4:26 p.m. I must confess that I am shocked by such disrespect shown to this court by the Sarnia Police. ${ }^{112}$

Instead of sending counsel to the hearing, the Sarnia Police had their counsel write a letter to CN's counsel. The text of that letter was provided to Justice Brown. The letter made extensive reference to the police's approach to the rule of law in the circumstances:

At present, the Service remains active with other members of the community, both political and industrial, in its search for a negotiated solution to this situation. No doubt that you appreciate that the Service (and its officers), on a daily basis, is tasked with the arduous challenge of policing in a jurisdiction where respect for aboriginal interests and issues must be reconciled with "the rule of law". Today, the citizenry of Sarnia has been very well served by this progressive and forward thinking approach.

The Service has read and reviewed the Order and believes it imperative that it maintain its discretion when it comes to the enforcement of same. For the time being, and while efforts are being made to find a peaceful solution to this situation through an amalgamation of community partners, the Service is of the view that a more pro-active approach, by the police, would be detrimental not only to the interests of CN Rail and the industrial area affected by the blockage, but also to the safety of the community at large.

A more rigid application of the rule of law would also undo much of the goodwill that the Service has created with the aboriginal members of the community that it serves. The Service believes that maintaining its discretion is imperative to the proper policing of this jurisdiction and thus to the safety of the public at large. ${ }^{113}$

The role of social media in organizing protests (resulting in leaderless protests) and in obtaining evidence has increased exponentially in recent years. See Tara Jeffrey, "Staff Sgt Takes Part in Drum Session," The London Free Press (31 December 2012), online: <www.lfpress.com/2012/12/31/staff-sgtoffers-show-of-goodwill>.

111 See generally CNR, supra note 11 at paras $1-25$.

112 Ibid at para 21.

$113 \quad$ Ibid at para 22. 


\title{
Justice Brown took a different view and expressed himself as follows:
}

With all due respect to the Sarnia Police, local police agencies cannot ignore judicial orders under the guise of contemplating how best to use their tactical discretion. Such an approach would have the practical effect of neutering court orders. It is not the purpose of a court order simply to initiate talks or consultations between the police and those whom the court has found to have breached the law. A court order is not one amongst several chips to be played in an ongoing contest between the police and transgressors of legal rights. On the contrary, a court order is intended to initiate the process of bringing unlawful conduct to an end in a short period of time so that the harm which the court has found to be irreparable is brought to an end. ${ }^{114}$

Justice Brown recognized that the police enjoy some discretion when enforcing court orders as to the time and manner of enforcement, but, in his view, that discretion is decidedly limited. He addressed the unwillingness of the Sarnia Police to enforce the injunction Order as follows:

\begin{abstract}
Canadian courts adjudicate claims alleging the violation of legal rights, and our courts pronounce or declare legal remedies. But courts lack the power to enforce that which they declare. In a real where-the-rubbermeets-the-road sense, our courts are powerless. Our effectiveness and our legitimacy lie in the hands of the political branches of government which possess the monopoly over the public instruments of force.
\end{abstract}

Where a court orders the cessation of unlawful conduct and calls on the assistance of police agencies to achieve that result, including through the use of force to arrest transgressors and remove obstructions, the court recognizes that the police must retain, to a degree, a tactical discretion to choose the time and manner of enforcement.

However, such discretion of the police is circumscribed in a very important way - the judicial decision that certain misconduct must end must be brought about in a timely way by the police.

As a judge, I make an order expecting it will be obeyed or enforced. If it will not be enforced, why should I make the order? An order which will not be enforced is simply a piece of paper with meaningless words typed on it, and making a meaningless order only undermines the authority and concomitant legitimacy of the courts. ${ }^{115}$

Justice Brown declined to set down the requested contempt hearings. Furthermore, he also declined to schedule CN's motion requiring the Sarnia Chief of Police to appear to explain what steps the service had taken to enforce the order given that counsel's letter made it clear they were not intending to enforce the order. He also ordered that future proceedings take place in the courts closest to the blockade. 
The blockade continued for almost two weeks, ending only after Ron Plain appeared before another Superior Court Justice who forcefully told Plain that the blockade had to stop, which it did some hours after that Justice's deadline expired.

Idle No More protests continued and matters escalated for $\mathrm{CN}$ at around 4:00 p.m. on Saturday, 5 January 2013. A new group of protestors blocked the Toronto-Montreal mainline of CN. Shortly before 9:20 p.m., CN appeared before the beleaguered Justice Brown to seek a second ex parte injunction. He ordered that the blockade cease no later than 12:01 a.m. on Sunday, 6 January 2013.

While the protestors left the site around 12:00 a.m., it was not because of any police assistance in enforcing the new injunction. Justice Brown expressed his frustration at this and at the Sarnia situation as a whole:

Let me turn to address one final matter which I considered when deciding whether to issue the injunction order. We seem to be drifting into dangerous waters in the life of the public affairs of this province when courts cannot predict, with any practical degree of certainty, whether police agencies will assist in enforcing court injunctions against demonstrators who will not voluntarily cease unlawful activities, such as those carried on by the protesters in this case. Just over two weeks ago, on December 21, 2012, I issued an injunction requiring First Nation protesters blocking a CN spur line in Sarnia to remove "forthwith" their obstructions. To my astonishment, the local police failed to assist in enforcing that order until January 2, 2013, under pressure from another judge of this court, a passage of almost two weeks. In that case, the failure of a police agency to assist in enforcing a court order prompted me to query whether, as a matter of the balance of convenience analysis, a court should take into account the willingness of the local police agency to enforce a court order.

Saturday night I made a time-sensitive order because the evidence showed that significant irreparable harm resulted from each hour the blockade remained in place, yet the OPP would not assist the local sheriff to ensure the order was served by the time stipulated for the removal of the blockade. Such an approach by the OPP was most disappointing because it undercut the practical effect of the injunction order. That kind of passivity by the police leads me to doubt that a future exists in this province for the use of court injunctions in cases of public demonstrations. 116

This set of circumstances does not always occur. Enforcement orders in recent injunctions issued in British Columbia appear to have been enforced with diligence. However, there remains a possibility that after bearing the considerable time and expense to obtain an injunction and an enforcement order, the police will refuse to enforce those orders in any event.

Some commentators have suggested an order in the nature of mandamus as a potential solution to this problem. In "Mandamus in the Enforcement of the Criminal Law: Ending the omitted]. 
Anti-Protest Injunction Habit," 117 Amir Attaran discussed the possibility of obtaining relief directly from the government in the form of mandamus as one such alternative in the face of civil disobedience, where law enforcement will not intervene. An application for mandamus would require separate proceedings being instituted against the government entity at issue, effectively bypassing the persons engaged in civil disobedience. As Attaran explains:

[M]andamus is allowed against a Crown servant who is persona designata in the performance of a particular duty. This opens the door to seeking a remedy against the commissioner of police, who is responsible under both the common law and statute to enforce the criminal law, as well as the Attorney General, who is statutorily charged with the administration of justice. ${ }^{118}$

Attaran's support for using mandamus to quell civil disobedience was grounded in a critique of the civil injunction process:

Taken together, the Attorney General and RCMP policies create a regime in which public authorities foreclose the use of the Criminal Code offences relevant to civil disobedience and blockading - such as mischief, intimidation, breach of the peace, contempt, and so on-leaving only remedies in private law. To put it politely, this is a perverse way to administer justice, since the definitive feature of civil disobedience is that it is protest coupled with the wilful violation of law. ${ }^{119}$

Interestingly, there do not appear to be any decided cases in which a court has had to determine whether mandamus is an appropriate remedy in the face of police reticence to enforce an order against those engaged in civil disobedience. In Slocan, ${ }^{120}$ the Attorney General of Canada took the position that the Court could not consider an order in the nature of mandamus directing the RCMP to act because the exclusive authority to make such an order, if appropriate, was vested in the Federal Court. These submissions were directed at the possible options raised in Attaran's article. However, there being no application for mandamus before him, Justice McEwan did not address this jurisdictional objection.

The fact that mandamus has not emerged as a viable alternative to civil injunctions may result from the practical difficulties in obtaining this particular form of relief. First, an order of mandamus directing public authorities to undertake certain actions is essentially a form of a mandatory injunction, which would require the applicant to satisfy a more burdensome test than for a prohibitory injunction. ${ }^{121}$ For example, mandatory orders require precise definition of the actions that must be undertaken. ${ }^{122}$ This would be particularly concerning in the context of an injunction requiring intervention in a potentially violent situation. If the order required intervention at a specific time and in a specific manner, law enforcement officials may be forced into situations that are unreasonably dangerous when better

117 Attaran, supra note 9.

118 Ibid at 185 [footnotes omitted] [emphasis in original].

119 Ibid at 183 [footnotes omitted] [emphasis in original].

120 Supra note 3.

121 See discussion in The Honourable Mr Justice Robert J Sharpe, Injunctions and Specific Performance (Toronto: Thomson Reuters, 1992) (loose-leaf release No 25, November 2016) at 1.500-1.815, 3.900.

$122 \quad$ Ibid at 1.410. See also Board of Education of Dysart School District $v$ Board of Education of Cupar School Division No 28 (1996), 148 Sask R 41 (CA). 
alternatives are available. It would be difficult, if not impossible, to draft an order that sufficiently retains police discretion while also requiring meaningful intervention.

Thus, it seems that while civil injunctions may be an imperfect vehicle for obtaining relief in the face of civil disobedience, no viable alternative has emerged, despite the fact that a refusal by police to enforce an injunction may lead to an impasse, as in the CNR case.

\section{Conclusion}

Private parties seeking to bring an end to acts of civil disobedience cannot rely upon law enforcement agencies to unilaterally respond to such conduct, notwithstanding the fact that it is unlawful. Despite the frustrations expressed by the courts in the late 1990s and early 2000 s with respect to the necessity for court ordered injunctions to address violations of public law, the policy of law enforcement to remain neutral in the context of civil disobedience remains largely in effect. Accordingly, the only practical recourse to address acts of civil disobedience is for a private party to obtain an injunction with appropriate enforcement provisions to enjoin the unlawful conduct. 
[this page is intentionally blank] 